\title{
Does the invasive species Reynoutria japonica have an impact on soil and
}

\section{flora in urban wastelands?}

Noëlie Maurel, Sandrine Salmon, Jean-François Ponge, Nathalie Machon, Jacques Moret, Audrey Muratet

N. Maurel, N. Machon, A. Muratet UMR 7204 MNHN/CNRS/UPMC, CP 53, 61 rue Buffon, 75005 Paris, France, e-mail:

maurel@mnhn.fr

N. Maurel, J. Moret Conservatoire Botanique National du Bassin Parisien, 61 rue Buffon, 75005 Paris, France

S. Salmon, J.-F. Ponge UMR 7179 MNHN/CNRS, 4 avenue du Petit Château, 91800 Brunoy, France

\begin{abstract}
Invasive plants are recognised as a major threat to biodiversity. Although they are well-established in natural areas, the supposed negative impacts of invasive plants upon communities and ecosystems have so far been poorly investigated in urban areas, where invasions are a main issue for ecologists and for urban planners and managers. We propose to assess the effects of an invasive species along an invasion gradient in a typical urban habitat. We focused on the Japanese knotweed (Reynoutria japonica Houtt.), a widespread invasive species in Europe and North America. We considered eight urban wastelands invaded by this species in the heart of the Greater Paris Area, France. On each site, we ran four transects from the centre of the Japanese knotweed patch towards the uninvaded peripheral vegetation. We recorded the flora using the line intercept method, and several soil parameters (thickness of A horizon, abundance of earthworm casts, topsoil Munsell value, $\mathrm{pH}$ ) every metre along each transect. The A horizon was thicker and the topsoil darker under $R$. japonica canopy. Thus, this invasive plant species seemed to influence soil organic matter pool. However, our results also steadily showed that R. japonica locally excluded and/or severely reduced the cover of many plant species through competition. Our study clarified the local effects of R. japonica: an influence on the soil organic matter, and a severe negative impact on wasteland plant communities. We suggest implications in both conservation and restoration ecology.
\end{abstract}

Keywords Competition, Organic matter, Japanese knotweed, Wasteland plant community, Fallopia japonica, Polygonum cuspidatum 


\section{Introduction}

Human-mediated species introductions have dramatically increased in recent decades with the expansion of longdistance trade (Westphal et al. 2008) and are leading to global biotic homogenisation (McKinney and Lockwood 1999; Olden 2006). Biological invasions are now regarded as a significant component of global change (Vitousek et al. 1997), one of the major threats to biodiversity on Earth (Gurevitch and Padilla 2004), and a central issue in conservation biology. In plant communities, the success and impacts of invasive species (sensu Richardson et al. 2000) have been thoroughly studied in natural and semi-natural areas, where they are often harmful to native ecosystems. Not only can they alter floristic composition and diversity (Meiners et al. 2001), and the successional dynamics of vegetation (Yurkonis and Meiners 2004), but they can also disrupt soil properties (Ehrenfeld 2003; Vanderhoeven et al. 2005) and soil biota (Wolfe and Klironomos 2005; see Bohlen 2006 for a review). Moreover, several studies have suggested positive feedbacks: invasive species change soil biota and/or soil biogeochemistry in ways that benefit themselves at the expense of native species (Klironomos 2002; Levine et al. 2006). In addition, these positive feedbacks may contribute to 'invasional meltdown', i.e. a process by which invasive species aid one another, leading to an increased rate of establishment and/or an impact at the community level (Simberloff and Von Holle 1999; Simberloff 2006).

Urban areas are particularly prone to plant invasions (Trepl 1995; Pysek 1998): many exotic plants are deliberately introduced for ornamental purposes (Reichard and White 2001), and urban areas are focal points for trade and transport (roads, railways and waterways, harbours and airports), which convey many exotic plant species and maintain a high level of propagule pressure (Vilà and Pujadas 2001; McKinney 2004; von der Lippe and Kowarik 2007). Several consequences may arise from this increase in the probability of species introductions. Predicting the impact of invasions on urban plant communities is not straightforward. Since invasive plant species commonly establish in disturbed, vulnerable communities that are far from ecological equilibrium (Kowarik 1995; Niemelä 1999; Williams et al. 2005; Godefroid et al. 2007; Muratet et al. 2007), it can be assumed that they are a major threat to local urban plant communities. All the more since, according to the 'invasional meltdown' theory, invasive species tend to invade the same sites, and thus may have more impact on native communities than predicted by summing independent effects. In contrast, it can be assumed that existing strong urban pressures select against 'weak' species, and that the remaining species are successful competitors, which are less likely to be affected by invasive species, even the most competitive. 
Despite the success of urban ecology (Miller and Hobbs 2002; Sukopp 2002; Adams 2005) and the emergence of reconciliation ecology (Rosenzweig 2003), it is striking to note that little has been published about plant invasions in cities. Thus there is a need to assess the impact of invasive plant species in urban areas.

In this study, we aimed at better understanding invasion processes and the threats caused by invasive species in cities. We examined the influence of an invasive plant species, Japanese knotweed (Reynoutria japonica Houtt.), on native plant communities and soil characteristics within invaded sites of the Greater Paris Area (France). This species is one of the " 100 of the world's worst invasive alien species" (Lowe et al. 2000) and is often considered a prominent disturbance by managers of urban green spaces and parks. We focused on urban wastelands, a habitat frequently colonised by $R$. japonica that plays a major role in urban biodiversity, since they are numerous and widespread, exhibiting the highest floristic richness of all urban plant communities (Muratet et al. 2007, 2008). In its introduced range, $R$. japonica has been shown to alter plant and invertebrate species diversity in natural riparian habitats (Gerber et al. 2008). We investigated whether similar floristic patterns occurred in urban areas. Furthermore, R. japonica influences soil nitrogen patterns in its native range (Hirose and Tateno 1984) and is known to produce large amounts of biomass, often more than do other plants of invaded communities (Dassonville et al. 2007). Therefore we hypothesised that R. japonica was likely to affect ecosystem process, resulting in changes in the soil organic matter pool.

Consequently, we addressed the following questions: (1) how does $R$. japonica influence the floristic richness and composition of plant communities in urban wastelands? (2) Does the presence of $R$. japonica modify the soil organic matter pool?

\section{Materials and methods}

Study species

Japanese knotweed ( $R$. japonica Houtt., Polygonaceae) is a perennial geophyte with bamboo-like annual stems up to 3 m tall and a deep rhizome network, which forms dense patches (Beerling et al. 1994; Smith et al. 2007). Native to Japan and eastern Asia, it was introduced in Europe and North America in the early nineteenth century. R. japonica grows in riparian habitats, but this opportunistic species tolerates a broad range of soil and climate conditions, and is also widely distributed in artificial, disturbed areas such as wastelands or road and railway banks (Müller 2004). 
Study area

The study was carried out in the heart of the Greater Paris Area $\left(48^{\circ} 51^{\circ} \mathrm{N} ; 2^{\circ} 21^{\circ} \mathrm{E}\right.$; Fig. 1), which consists of about $70 \%$ urbanised areas (IAURIF 2003) and a human density of 8,501 versus 112 inhab./ $\mathrm{km}^{2}$ on average in France (INSEE 2006). The climate is oceanic with continental trends: the mean annual temperature is $11.7^{\circ} \mathrm{C}$ with $16^{\circ} \mathrm{C}$ thermal amplitude and an average annual rainfall of $641 \mathrm{~mm}$. We chose to focus on urban wastelands, defined as abandoned lands where plant species grow with no human control (Muratet et al. 2007).

Site description

Eight sites, all invaded by $R$. japonica, were included in this study (Fig. 1). The site list was provided by the floristic database of the National Botanical Conservatory of the Parisian Region (CBNBP 2008). We mapped the sites and we calculated their area using a Geographic Information System (MapInfo 8.5, MapInfo Corporation 2006). Land Use Patterns (LUP) were provided by IAURIF (2003) and grouped into nine major LUP classes. Six successive LUP updates are available from 1982 to 2003, allowing estimating the age of sites. Consistently with the results of Muratet et al. (2007), six of the eight sites belonged either to "building sites and vacant urban" (BUILVAC) class, or to “open urban areas and rural" (OPENRUR) class. Only W3 and W4 were located respectively in "facilities" (FACI) and "transport" (TRAN) classes, corresponding to rather small unused spaces in the built matrix. Also consistently with Muratet et al. (2007), half of the sites (W2, W4, W6, W7) were older than 21 years (in the same LUP class since 1982), whereas two sites were less than 9 years old (W3, W5) and the two remaining (W1, W8) were of intermediate age. The characteristics of all sites are summarised in Table 1.

Sampling strategy

Paired-sites comparisons are controversial: when differences are observed between invaded and uninvaded sites, either they result from a differentiation triggered by the invasive species, or they merely reflect differences preexisting the invasion event. Therefore other studies resort to within-site comparisons, where uninvaded control plots are located as close as possible to the 'invasion front' (e.g. Vanderhoeven et al. 2005; Dassonville 2008). Similarly, 
we focused on sites already invaded by $R$. japonica and we compared patches of $R$. japonica (invaded area) with the surrounding uninvaded area.

Each site displayed at least one patch of $R$. japonica surrounded by a continuous herbaceous cover of different heights, sometimes mixed with shrubs. Patches were circular to oval-shaped, with a well-delineated 'invasion front'. They ranged from 10 to $74 \mathrm{~m}^{2}$, i.e. from 0.038 to $3.26 \%$ of the entire site (Table 1 ).

Floristic composition (Kerguélen 2003), floristic richness, vegetation cover and soil parameters were assessed along four transects arranged in a cross shape, running from the centre of the invaded area towards the peripheral uninvaded area, at right-angles to the 'invasion front' (see Wearne and Morgan 2004 or Maerz et al. 2005 for a similar design). Contrary to isolated paired plots, line transects allowed detecting gradual changes with the expanding of the invading population, so that the distance from the centre of the patch could be considered as a proxy of invasion time. Transects were centred on the invasion front, with an identical length within and outside the patch, thus the length of the whole transect ranged from 3 to $22 \mathrm{~m}$. One of the sites (W5; Fig. 1) was destroyed before all four transects were inventoried, therefore only two transects were surveyed for W5.

\section{Data collection}

We conducted our study in May 2007. The vascular flora was sampled along each transect using the line intercept method (Canfield 1941): all vascular plant species other than $R$. japonica that intercepted the transect line were recorded every centimetre. We classified species as 'native' versus 'exotic', according to a list compiled by professional botanists of the National Botanical Conservatory of the Parisian Region (CBNBP 2008).

Transects were split up into $0.5 \mathrm{~m}$ sections (see Fig. 3). We calculated species richness and estimated the total cover (non-bare ground) of the herbaceous layer, $R$. japonica excepted, in each section.

Several soil parameters were recorded every metre along each transect, on a ground sample of $20 \mathrm{~cm}^{2}$. We measured (1) the abundance of earthworm casts at the soil surface (observations grouped into three classes: $0=$ no earthworm casts, 1 = few earthworm casts, i.e. covering less than $25 \%$ of the sample, $2=$ abundant earthworm casts, i.e. covering more than $25 \%$ of the sample), (2) the thickness of the A horizon (cm), (3) the soil colour in the top five centimetres, according to the Munsell Soil Color Charts (Munsell Color Company 1975): the colour "value" ranges 
from 1 to 5 and decreases with the amount of organic matter (Wills et al. 2007). We also recorded (4) soil pH- $\mathrm{H}_{2} \mathrm{O}$ : the $\mathrm{pH}$ was measured using a Fisher Scientific $\mathrm{pH}$-meter, $3 \mathrm{~h}$ after soil was oven-dried at $40^{\circ} \mathrm{C}$ for $36 \mathrm{~h}$ and mixed with deionised water (soil:water 1:5 v/v) for 5 min (AFNOR 1999).

Data analysis

We analysed the variation of four soil parameters formerly tested for independence: (1) thickness of the A horizon, (2) abundance of earthworm casts, (3) topsoil Munsell value (colour parameter) and (4) pH, through linear mixed-effect models with section as a fixed effect and site as a random effect (using nlme package, Pinheiro and Bates 2000). Because of insufficient replicates, sections ' $-11 \mathrm{~m}$ ' to' $-6 \mathrm{~m}$ ' were grouped into one single class ('<-5 m'), and similarly, sections ' $6 \mathrm{~m}$ ' to ' $11 \mathrm{~m}$ ' were grouped into class ' $>5 \mathrm{~m}$ '.

Within each site, we assessed differences in floristic composition between invaded and uninvaded areas through distance-based redundancy analysis, an ordination method which compares distances among groups (dbRDA, Legendre and Anderson 1999). We calculated the floristic distances df between and within uninvaded areas and invaded areas via the Jaccard similarity sf index as follows (using ADE4 package, Thioulouse et al. 1997):

$\mathrm{df}=\sqrt{ }(1-\mathrm{sf})$

where sf is the fraction of species observed in both sites. We then performed dbRDA, to explore the relationship between floristic distances and the "invasion" variable. To graphically display the results, we used Nonmetric Multidimensional Scaling.

We analysed the variation of (1) species richness and (2) total percent cover as a function of the section's location (a proxy of 'invasion effect') using linear mixed-effect models with section as a fixed effect and site as a random effect. Because of insufficient replicates, sections ' -11 m'to'-6.5 m' were grouped into one single class ('<-6 m'), and similarly, sections ' 6.5 m' to ' 11 m' were grouped into class ' $>6 \mathrm{~m}$ '.

Due to the small number of replicates (2) and to lacking data for the A horizon and $\mathrm{pH}$, site W5 was discarded from composition analyses, and from all analyses involving soil parameters, while it was kept for richness and cover analyses. 
Statistical analysis were performed using R software (R 2.8.0, R Development Core Team 2008).

\section{Results}

Excluding $R$. japonica, a total of 83 species were observed along the 30 transects we inventoried, with an average of $23 \pm 3(\mathrm{SE})$ species per site (Table 1). Among these, $86.7 \%$ were native, $13.3 \%$ were exotic.

The species most frequently found were Dactylis glomerata (8/8 sites), Galium aparine (7/8 sites), Elytrigia repens, Picris hieracioides, and Plantago lanceolata (all in 6/8 sites).

Impact of $R$. japonica on wasteland soil

Globally, the thickness of the A horizon decreased significantly from the centre of $R$. japonica patches towards uninvaded periphery $(\mathrm{P}<0.0001$; Fig. 2a) while the topsoil Munsell value increased significantly $(\mathrm{P}<0.0001$; Fig. 2b). On average, the A horizon was (mean \pm SE) $2.77 \pm 0.09 \mathrm{~cm}$ thick in invaded areas versus $1.72 \pm 0.07 \mathrm{~cm}$ in uninvaded areas, and the topsoil Munsell value was $2.92 \pm 0.07$ under $R$. japonica versus $3.54 \pm 0.06$ in adjacent uninvaded vegetation.

On the contrary, the abundance of earthworm casts did not differ significantly along transects $(\mathrm{P}=0.64)$, nor did the $\mathrm{pH}(\mathrm{P}=0.17)$.

Impact of $R$. japonica on wasteland flora

Species richness and total percent cover increased significantly from the centre of $R$. japonica patches towards adjacent uninvaded vegetation $(\mathrm{P}<0.0001$ for both models, Fig. $3 \mathrm{a}, \mathrm{b} ; R$. japonica is excluded from analyses and figures).

Species composition differed significantly between uninvaded and invaded area for sites W6 and W7 (P = 0.001 for each of them in dbRDA tests, Fig. $4 a, b$ ). In contrast, no difference in species composition was detected between uninvaded areas and areas invaded by $R$. japonica for sites W1, W2, W3, W4 and W8 (respectively, $\mathrm{P}=$ 
$0.613, \mathrm{P}=0.690, \mathrm{P}=0.081, \mathrm{P}=0.067, \mathrm{P}=0.699 ;$ Fig. $4 \mathrm{c})$.

\section{Discussion}

Impacts of $R$. japonica on soil

In the wastelands studied, soils were quite variable among sites, making it difficult to detect any effect of $R$. japonica. However, despite the variability of all edaphic parameters, we observed a thicker A horizon, as well as a darker topsoil under R. japonica as compared to the surrounding uninvaded area. Altogether, these results led us to argue for a strong influence of $R$. japonica on the soil organic matter pool.

These results could be explained by the massive production of annual aboveground and permanent belowground biomass (Dassonville et al. 2007). According to Maerz et al. (2005) and Dassonville (2008), R. japonica provides abundant but low-quality litter, and stems and leaves decay slowly, resulting in the accumulation of large, rough fragments, and in an increase in litter thickness (personal observation). Added to the slightly alkaline soils (pH ranging from 7.2 to 8.3), this organic matter supply could result in a darker topsoil and a thicker A horizon.

Ehrenfeld (2003) suggested that invasive plants could enhance productivity and nutrient availability in invaded areas via an abundant litter, thereby increasing their own success. Although our study did not allow showing evidence for such a process, it is possible that $R$. japonica contributes to its own growth and productivity by creating a positive plant-soil feedback.

Nevertheless, this apparent soil enrichment may especially benefit very common eutrophic species, such as the nitrophilous $G$. aparine, frequently observed in the invaded areas.

Impacts of $R$. japonica on plant communities in urban wastelands

As expected, there was an important decrease in herbaceous cover under $R$. japonica, largely due to the competitive exclusion of most grasses and forbs. Poaceae are a meaningful example: they covered almost $40 \%$ of uninvaded areas, but only $8 \%$ of invaded areas. The herbaceous community was also clearly poorer under $R$. japonica. We cannot completely exclude that $R$. japonica systematically established in quasi-bare grounds (differences would then pre-exist the 
invasion). However, our sampling design allowed us detecting gradual changes along transects, therefore we assume that $R$. japonica was rather responsible for an impoverishment of plant communities, i.e. these differences in richness and cover followed, and not pre-existed, the invasion by $R$. japonica. This could be ascribed to the competitive ability of this invasive species. $R$. japonica could win both aboveground and belowground competition, thanks to a high growth rate, the production of large amounts of biomass (Beerling et al. 1994; Dassonville et al. 2007), the efficiency of leaves to intercept light (see the experiment conducted on the close Reynoutria $\mathrm{x}$ bohemica by Siemens and Blossey 2007), the early use of space and soil resources, and possible allelopathic interactions (Vrchotova and Sera 2008). Thus, $R$. japonica could become a long-term dominant species in invaded plant communities, forming dense, homogeneous, near monospecific patches.

Thus, after patterns of competitive exclusion were shown for European and North American riparian habitats (Gerber et al. 2008), we showed that similar patterns can be observed in urban areas also.

Despite the strong impacts on diversity and vegetation abundance, the effects of $R$. japonica on floristic composition are more questionable. Differences were significant in only two sites. On average the proportion of flora growing in invaded areas represented 59\% of the species versus $90 \%$ in uninvaded areas. Some species were never or rarely recorded under $R$. japonica, like P. lanceolata, Achillea millefolium or P. hieracioides. On the contrary, others frequently coexisted with R. japonica, like Rubus fruticosus, Urtica dioica and G. aparine. Gerber et al. (2008) had already found the latter two species to persist under $R$. japonica canopy in riparian habitats.

However, across all sites, $R$. japonica patches represented at most less than $4 \%$ of the whole surface of the site. This slightly balances our results: $R$. japonica deeply impacts plant communities at local scale, but these effects are questionable at larger scale. In particular, in a very dynamic urban landscape, the high turnover of wasteland sites could prevent $R$. japonica to dramatically expand after establishing, and at the same time it could create new open spaces where plant species could find favourable conditions for growing.

\section{Perspectives in restoration biology}

Our study stressed the relevance of soil-plant relationships in the area of plant invasions. Soil characteristics can partly control the establishment of an invasive plant species, including in disturbed areas, as demonstrated by Kulmatiski et al. (2006) in abandoned agricultural fields. In return, invasive plant species, once established, can 
modify soil abiotic and biotic components. As such, our observations supported the conceptual sketch suggested by Wolfe and Klironomos (2005): the arrival of an exotic species in an ecosystem influences the links between plant community composition, soil community composition, and ecosystem processes and properties. Studies of plant invasions increasingly explore the effects of invasive plants on soils (Vitousek 1990; Ehrenfeld 2003; Levine et al. 2003). Some authors emphasise that these effects matter for the restoration of local flora, as higher nitrate content, for example, can inhibit the growth of several native species, alter dominance relationships in the plant community, and hence curb the restoration process (Kourtev et al. 1999; Yu et al. 2005).

In practice, there are many attempts—rarely successful—-to remove $R$. japonica from invaded communities, both in natural riparian communities and in less natural areas, like urban green parks or urban forest remnants. In order to prevent $R$. japonica from growing again, river managers and urban planners usually associate such removal projects with greening projects, by planting trees, shrubs, forbs and/or grasses, depending on the vegetation structure they intend to create or restore. Soils are rarely—if ever-taken account of in their scheme. Some authors reported that the effects of an invasive plant on soil properties are very likely to persist even after its removal (Kourtev et al. 1999; Dassonville et al. 2007). Similarly, we can expect that soils would remain modified after the eradication of $R$. japonica, and that this could influence the restoration process, by favouring some species traits, such as eutrophy. Kourtev et al. (1999) also suggested that persistent soil changes could favour other exotic species. Although our data did not show evidence of such facilitation, we recommend managers to be very watchful with the evolution of floristic composition during restoration process.

Acknowledgments We are grateful to Emmanuelle Porcher for her help with statistical analyses and useful comments on this manuscript. We also thank Monika Zavodna and Claire Jouseau for their constructive comments on the draft.

This research was supported by the Région Ile-de-France and the Réseau Francilien de Recherche sur le Développement Soutenable (R2DS). Anne Lindsey corrected the English.

\section{References}

Adams LW (2005) Urban wildlife ecology and conservation: a brief history of the discipline. Urban Ecosyst $8(2): 139-156$ 
AFNOR (1999) NF ISO 10390. Qualité des sols, vol 2. AFNOR, Paris

Beerling DJ, Bailey JP, Conolly AP (1994) Biological flora of the British Isles. Fallopia japonica (Houtt.) Ronse Decraene. J Ecol 82(4):959-979

Bohlen PJ (2006) Biological invasions: linking the above-ground and belowground consequences. Appl Soil Ecol 32(1):1-5

Canfield RH (1941) Application of the line-intercept method in sampling vegetation. J Forest 39:388-394

Conservatoire Botanique National du Bassin Parisien (CBNBP) (2008). http://cbnbp.mnhn.fr/cbnbp

Dassonville N (2008) Impact des plantes exotiques envahissantes sur le fonctionnement des écosystèmes en Belgique. Thesis, Université Libre de Bruxelles, Bruxelles

Dassonville N, Vanderhoeven S, Gruber W, Meerts P (2007) Invasion by Fallopia japonica increases topsoil mineral nutrient concentrations. Ecoscience 14(2):230-240

Ehrenfeld JG (2003) Effects of exotic plant invasions on soil nutrient cycling processes. Ecosystems 6(6):503-523

Gerber E, Krebs C, Murrell C, Moretti M, Rocklin R, Schaffner U (2008) Exotic invasive knotweeds (Fallopia spp.) negatively affect native plant and invertebrate assemblages in European riparian habitats. Biol Conserv 141(3):646-654

Godefroid S, Monbaliu D, Koedam N (2007) The role of soil and microclimatic variables in the distribution patterns of urban wasteland flora in Brussels, Belgium. Landscape Urban Plan 80(1-2):45-55

Gurevitch J, Padilla DK (2004) Are invasive species a major cause of extinctions? Trends Ecol Evol 19(9):470-474

Hirose T, Tateno M (1984) Soil-nitrogen patterns induced by colonization of Polygonum cuspidatum on Mt. Fuji. Oecologia 61(2):218-223

IAURIF (2003) Institute for Planning and Development of the Paris Ile-de-France Region. http://www.iaurif.org

INSEE (2006) National Institute for Statistics and Economic Studies. http://www.insee.fr

Kerguélen M (2003) Base de Données Nomenclaturales de la Flore de France (BDNFF) version 3 
Klironomos JN (2002) Feedback with soil biota contributes to plant rarity and invasiveness in communities. Nature 417(6884):67-70

Kourtev PS, Huang WZ, Ehrenfeld JG (1999) Differences in earthworm densities and nitrogen dynamics in soils under exotic and native plant species. Biol Invasions 1(2-3):237-245

Kowarik I (1995) On the role of alien species in urban flora and vegetation. In: Pysek P, Prach K, Rejmanek M, Wade M (eds) Plant invasions-general aspects and special problems. SPB Academic Publishing, Amsterdam, pp $85-103$

Kulmatiski A, Beard KH, Stark JM (2006) Soil history as a primary control on plant invasion in abandoned agricultural fields. J Appl Ecol 43(5):868-876

Legendre P, Anderson MJ (1999) Distance-based redundancy analysis: testing multispecies responses in multifactorial ecological experiments. Ecol Monogr 69(1):1-24

Levine JM, Vila M, D’Antonio CM, Dukes JS, Grigulis K, Lavorel S (2003) Mechanisms underlying the impacts of exotic plant invasions. Proc R Soc London Ser B 270:775-781

Levine JM, Pachepsky E, Kendall BE, Yelenik SG, Lambers JHR (2006) Plant-soil feedbacks and invasive spread. Ecol Lett 9(9):1005-1014

Lowe S, Browne M, Boudjelas S, De Poorter M (2000) 100 of the World's Worst Invasive Alien Species. A selection from the Global Invasive Species Database. Invasive Species Specialist Group (ISSG)

Maerz JC, Blossey B, Nuzzo V (2005) Green frogs show reduced foraging success in habitats invaded by Japanese knotweed. Biodivers Conserv 14(12):2901-2911

MapInfo, MapInfo corporation (2006) MapInfo professional version 8.5. http://www.mapinfo.co.uk

McKinney ML (2004) Citizens as propagules for exotic plants: measurement and management implications. Weed Technol 18:1480-1483

McKinney ML, Lockwood JL (1999) Biotic homogenization: a few winners replacing many losers in the next mass extinction. Trends Ecol Evol 14(11):450-453 
Meiners SJ, Pickett STA, Cadenasso ML (2001) Effects of plant invasions on the species richness of abandoned agricultural land. Ecography 24(6):633-644

Miller JR, Hobbs RJ (2002) Conservation where people live and work. Conserv Biol 16(2):330-337

Müller S (2004) Plantes invasives en France. Muséum national d'Histoire naturelle, Paris

Munsell Color Company (1975) Munsell soil color charts. Baltimore, MD

Muratet A, Machon N, Jiguet F, Moret J, Porcher E (2007) The role of urban structures in the distribution of wasteland flora in the Greater Paris Area, France. Ecosystems 10(4):661-671

Muratet A, Porcher E, Devictor V, Arnal G, Moret J, Wright S, Machon N (2008) Evaluation of floristic diversity in urban areas as a basis for habitat management. Appl Veg Sci 11:451-460

Niemelä J (1999) Ecology and urban planning. Biodivers Conserv 8(1):119-131

Olden JD (2006) Biotic homogenization: a new research agenda for conservation biogeography. J Biogeogr 33:20272039

Pinheiro JC, Bates DM (2000) Mixed-effects models in S and S-PLUS. Springer, New York

Pysek P (1998) Alien and native species in Central European urban floras: a quantitative comparison. J Biogeogr 25(1):155-163

R Development Core Team (2008) R: a language and environment for statistical computing. R Foundation for Statistical Computing, Vienna

Reichard SH, White P (2001) Horticulture as a pathway of invasive plant introductions in the United States. Bioscience 51(2):103-113

Richardson DM, Pysek P, Rejmanek M, Barbour MG, Panetta FD, West CJ (2000) Naturalization and invasion of alien plants: concepts and definitions. Divers Distrib 6:93-107

Rosenzweig ML (2003) Win-Win ecology. Oxford University Press, New York

Siemens TJ, Blossey B (2007) An evaluation of mechanisms preventing growth and survival of two native species in 
invasive bohemian knotweed (Fallopia x bohemica, Polygonaceae). Am J Bot 94(5):776-783

Simberloff D (2006) Invasional meltdown 6 years later: important phenomenon, unfortunate metaphor, or both? Ecol Lett 9:912-919

Simberloff D, Von Holle B (1999) Positive interactions of nonindigenous species: invasional meltdown? Biol Invasions $1: 21-32$

Smith JMD, Ward JP, Child LE, Owen MR (2007) A simulation model of rhizome networks for Fallopia japonica (Japanese knotweed) in the United Kingdom. Ecol Model 200:421-432

Sukopp H (2002) On the early history of urban ecology in Europe. Preslia 74:373-393

Thioulouse J, Chessel D, Doledec S, Olivier JM (1997) ADE-4: a multivariate analysis and graphical display software. Stat Comput 7(1):75-83

Trepl L (1995) Towards a theory of urban biocenoses. Some hypotheses and research questions. In: Sukopp H, Numata M, Huber A (eds) Urban ecology as the basis of urban planning. SPB Academic Publishing, The Hague, pp 3-21

Vanderhoeven S, Dassonville N, Meerts P (2005) Increased topsoil mineral nutrient concentrations under exotic invasive plants in Belgium. Plant Soil 275(1-2):169-179

Vilà M, Pujadas J (2001) Land-use and socio-economic cor-relates of plant invasions in European and North African countries. Biol Conserv 100:397-401

Vitousek P (1990) Biological invasions and ecosystem pro-cesses: towards an integration of population biology and ecosystem studies. Oikos 57:7-13

Vitousek PM, D’Antonio CM, Loope LL, Rejmanek M, Westbrooks R (1997) Introduced species: a significant component of human-caused global change. New Zeal J Ecol 21(1):1-16

von der Lippe M, Kowarik I (2007) Long-distance dispersal of plants by vehicles as a driver of plant invasions. Conserv Biol 21(4):986-996

Vrchotova N, Sera B (2008) Allelopathic properties of knotweed rhizome extracts. Plant Soil Environ 54(7):301-303 
Wearne LJ, Morgan JW (2004) Community-level changes in Australian subalpine vegetation following invasion by the non-native shrub Cytisus scoparius. J Veg Sci 15(5):595-604

Westphal MI, Browne M, MacKinnon K, Noble I (2008) The link between international trade and the global distribution of invasive alien species. Biol Invasions 10(4):391- 398

Williams NSG, Morgan JW, McDonnell MJ, McCarthy MA (2005) Plant traits and local extinctions in natural grasslands along an urban-rural gradient. J Ecol 93(6):1203- 1213

Wills SA, Burras CL, Sandor JA (2007) Prediction of soil organic matter carbon content using field and laboratory measurements of soil color. Soil Sci Soc Am J 71:380- 388

Wolfe BE, Klironomos JN (2005) Breaking new ground: soil communities and exotic plant invasion. Bioscience 55(6):477-487

Yu XJ, Yu D, Lu ZJ, Ma KP (2005) A new mechanism of invader success: exotic plant inhibits natural vegetation restoration by changing soil microbe community. Chinese Sci Bull 50(11):1105-1112

Yurkonis KA, Meiners SJ (2004) Invasion impacts local species turnover in a successional system. Ecol Lett 7:764769 


\section{Figure captions}

Fig. 1 Map of the study area, showing the four administrative districts (French "départements") of the heart of the Greater Paris Area. Each point corresponds to a survey wasteland site

Fig. 2 Thickness of A horizon (a) and topsoil Munsell value (b) along transects as a function of the section's location (distance to invasion front inside or outside the patch)

Fig. 3 Species richness (a) and total percent cover (b) along transects as a function of the section's location (distance to invasion front inside or outside the patch). R. Japonica is excluded from this figure

Fig. 4 Floristic composition in invaded areas (IA) and uninvaded areas (UA) illustrated by Nonmetric Multidimensional Scaling (NMDS). W6 (Noisy-le-Grand, a) and W7 (Paris, b) display significant differences between IA and UA. For W2 (Champigny-sur-Marne, c) floristic composition is similar in IA and UA 
Table 1 Characteristics of the eight survey sites

\begin{tabular}{lllllll}
\hline Site & Borough & $\begin{array}{l}\text { Site area } \\
\left(\mathrm{m}^{2}\right)\end{array}$ & $\begin{array}{l}\text { Patch area } \\
\left(\mathrm{m}^{2}\right)\end{array}$ & $\begin{array}{l}\text { Proportion of the } \\
\text { site invaded by } R . \\
\text { japonica }(\%)\end{array}$ & $\begin{array}{l}\text { Sampled species } \\
\text { richness }\end{array}$ & $\begin{array}{l}\text { Proportion of exotic } \\
\text { species }(\%) \text { on the } \\
\text { transects }\end{array}$ \\
\hline W1 & Gennevilliers 1 & 11,600 & 66 & 0.56 & 31 & 16.1 \\
W2 & Champigny & 1,300 & 42.7 & 3.28 & 13 & 15.4 \\
W3 & Châtenay-Malabry & 5,200 & 10.2 & 0.19 & 15 & 0 \\
W4 & Colombes & 5,400 & 74.2 & 1.37 & 33 & 9.1 \\
W5 & Gennevilliers 2 & 3,000 & 35.9 & 1.20 & 19 & 11.1 \\
W6 & Noisy-le-Grand & 113,600 & 41.5 & 0.036 & 28 & 10.7 \\
W7 & Paris & 35,900 & 17.6 & 0.049 & 20 & 5 \\
W8 & Villetaneuse & 29,900 & 26.2 & 0.087 & 26 & 11.5 \\
& Global & & & 83 & 13.3 \\
& Mean & & & 23 & 9.9 \\
\hline
\end{tabular}




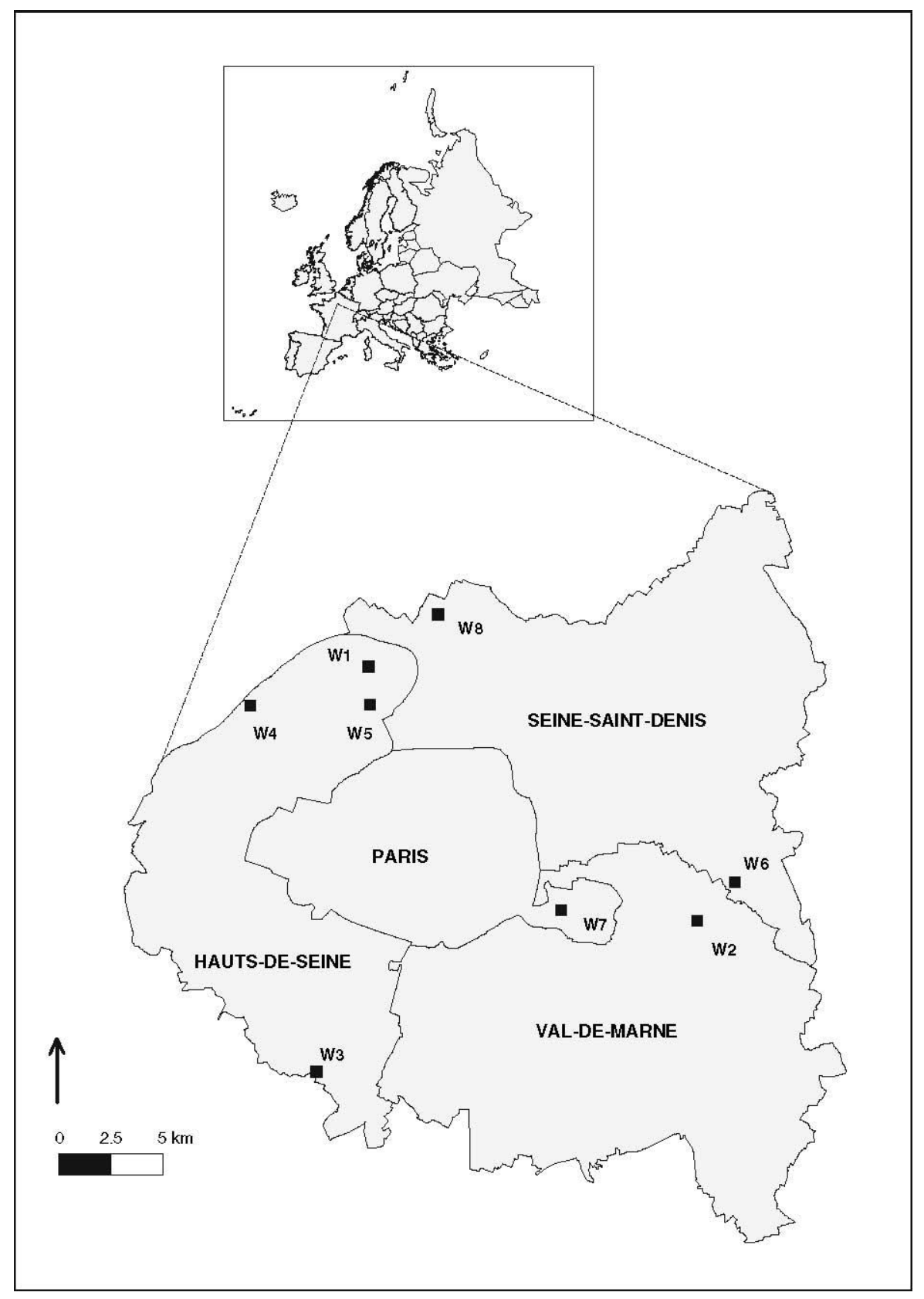

Fig. 1 

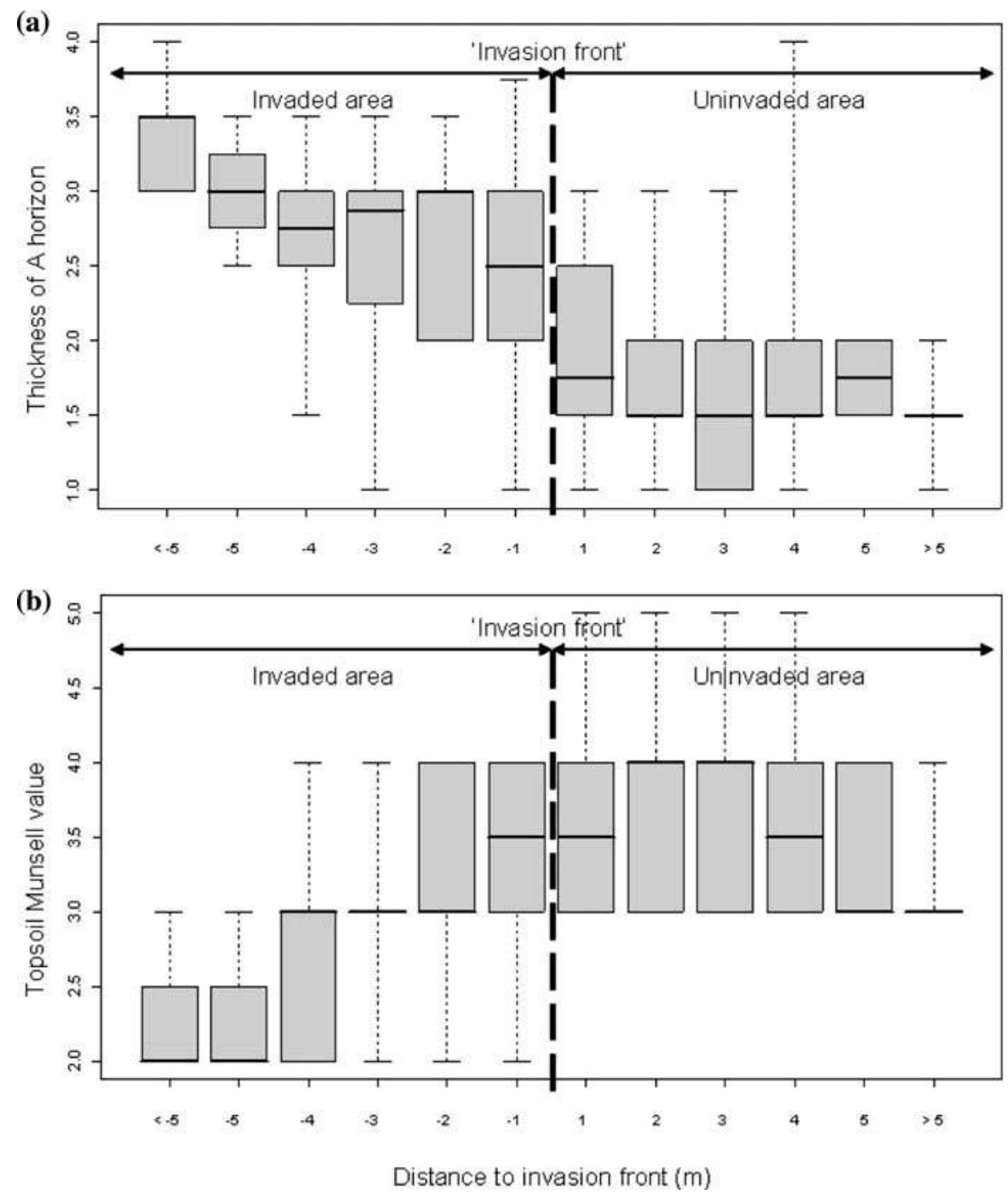

Fig. 2 

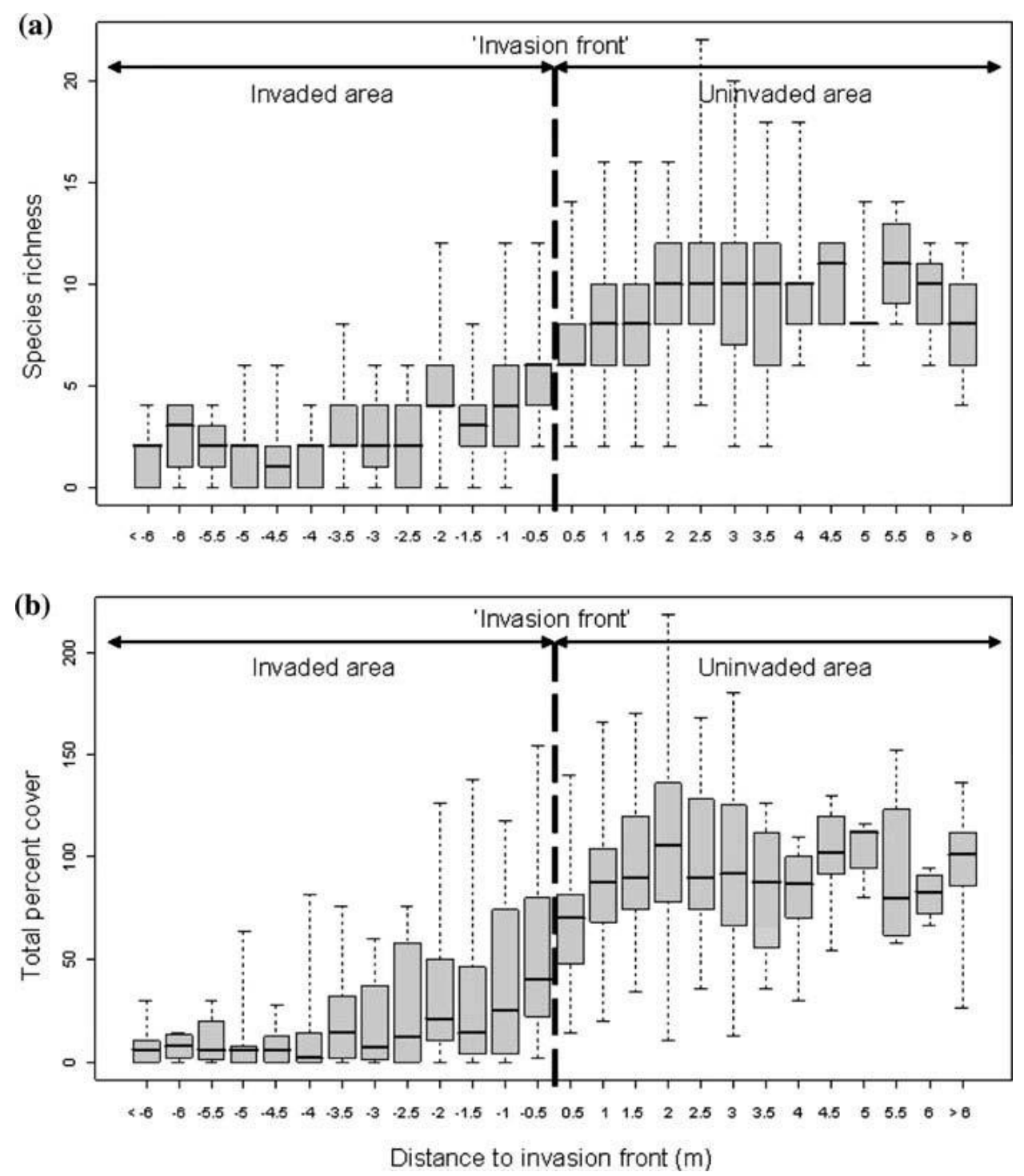

Fig. 3 

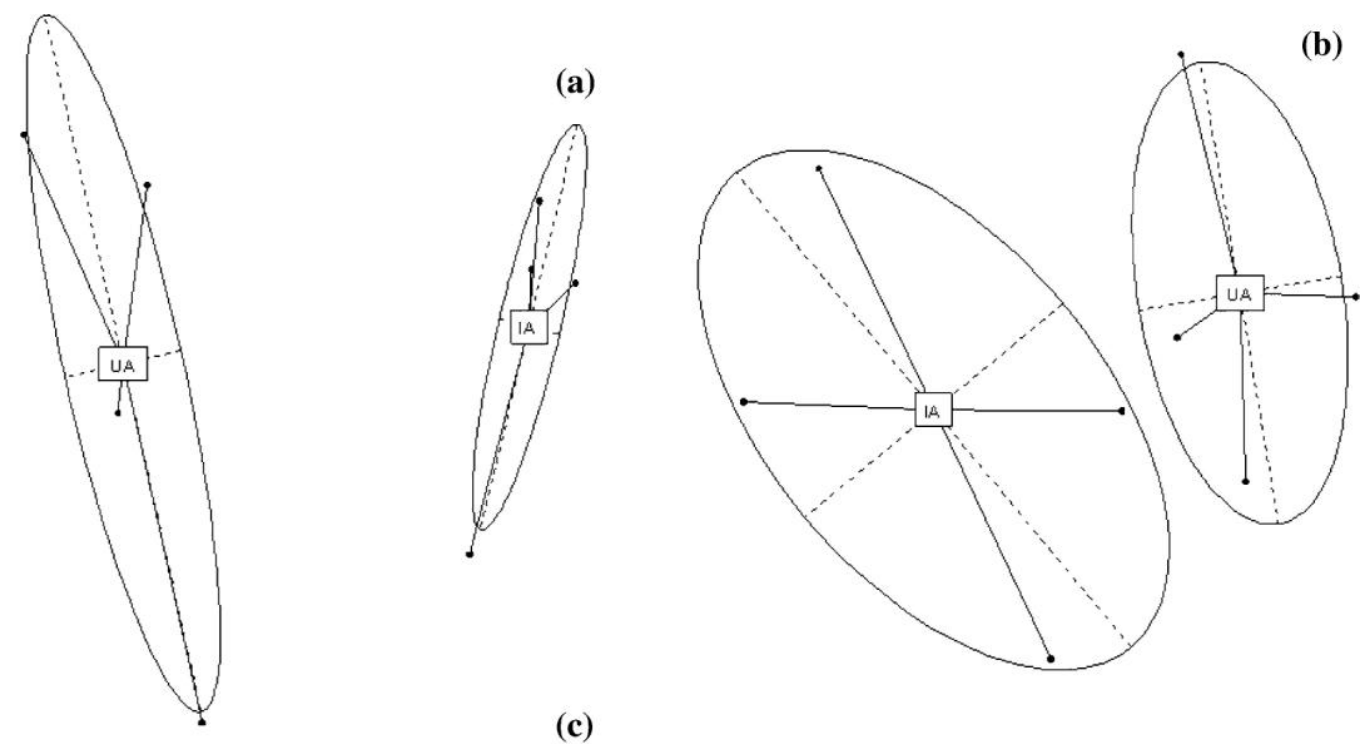

(c)

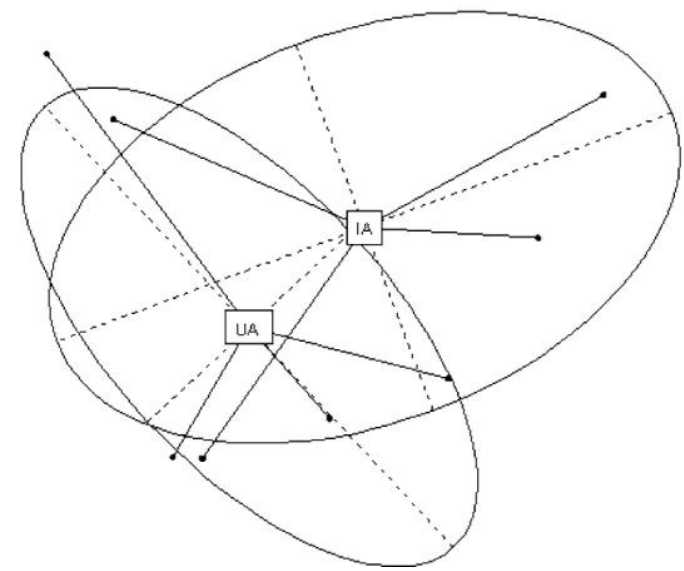

$\mid \mathrm{A}=$ Invaded Area

$\mathrm{UA}=$ Uninvaded Area

Fig. 4 